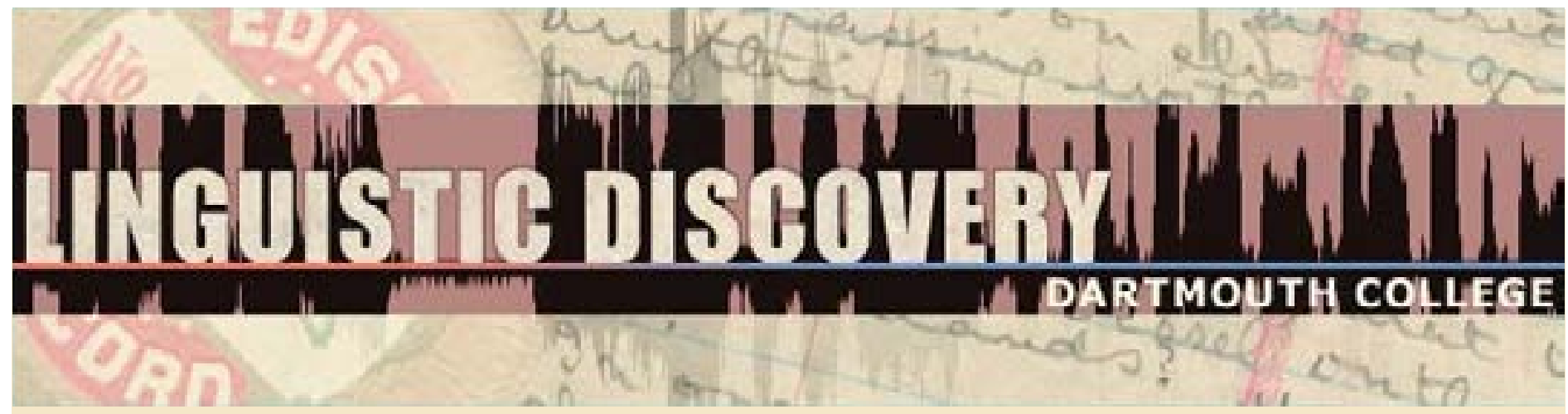

Volume 3

Issue 1 2005

\section{Argument Marking in Ditransitive} Alignment Types

Martin Haspelmath

Max Planck Institute for Evolutionary Anthropology

doi: 10.1349/PS1.1537-0852.A.280

url: http://journals.dartmouth.edu/cgi-bin/WebObjects/ Journals.woa/1/xmlpage/1/article/280 


\title{
Argument Marking in Ditransitive Alignment Types*
}

\author{
Martin Haspelmath \\ Max Planck Institute for Evolutionary Anthropology
}

This paper discusses the patterns of case-marking/adpositional marking and indexing of ditransitive clauses in the world's languages, i.e. clauses with an Agent, a Recipient and a Theme argument. It distinguishes three major alignment types, indirective, secundative, and neutral, corresponding to accusative, ergative and neutral in monotransitive constructions. The alignment and coding patterns are recorded for a sample of 100 languages from around the world. Ditransitive alignment is compared with monotransitive alignment, alignment of casemarking/adpositional marking is compared to alignment of indexing, and the various coding types are distinguished, depending on the occurrence of zero-coding and overt coding. Seven cross-linguistic generalizations emerging from the data are proposed as valid tendencies, and possible functional explanations for these tendencies are discussed.

\section{The major alignment types, monotransitive and ditransitive}

In syntactic typology, the monotransitive alignment types, in particular accusativity and ergativity, have been a major topic of research in recent decades (see Dixon 1994 for an overview). The picture that is shown in (1) has become standard textbook wisdom. If we use the well-known role-prototypes $\mathrm{S}$ (single argument of intransitive verb), A (agent-like argument of transitive verb) and P (patient-like argument of transitive verb), we can say that if S and A are treated alike as opposed to P, we get accusative alignment (as in 1a); if all three are treated alike, we get neutral alignment (as in 1b); and if $\mathrm{S}$ and $\mathrm{P}$ are treated alike as opposed to A, we get ergative alignment (as in 1c).

(1) The major monotransitive alignment types

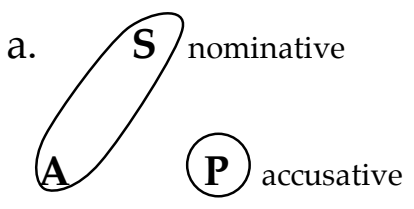

accusative alignment

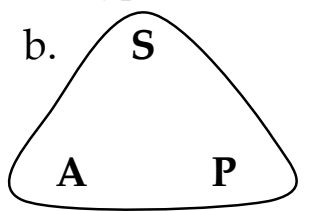

neutral alignment

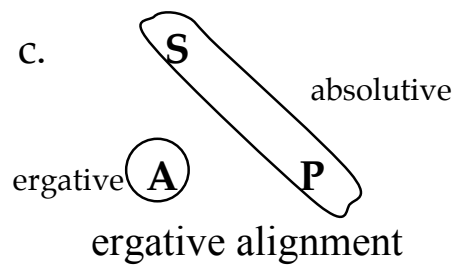

ergative alignment

Now as Dryer (1986) first pointed out (and see Croft (1990:100-108), Dryer To appear), the relationship between the two object arguments in ditransitive clauses can be conceptualized in exactly the same way. ${ }^{1}$ The role-prototypes in ditransitive clauses are $\mathrm{R}$ (recipient-like argument)

\footnotetext{
*An earlier version of this paper was presented at the Association of Linguistic Typology conference in Santa Barbara in July 2001. I am grateful to two Linguistic Discovery reviewers for comments that helped improve the paper.

${ }^{1}$ The term ditransitive is here used for clauses with a recipient-like and a theme-like argument, i.e. it is purely semantically defined. Some authors prefer to reserve the term for constructions in which both objects are treated like the monotransitive direct object. However, other terms are readily available for this concept (e.g. neutral ditransitive alignment, as in (2b), or double-object construction), whereas there are no good alternative terms for the concept intended here (apart from the clumsy "Recipient-Theme construction"). In particular, "three-place predicate" is not
} 
and $\mathrm{T}$ (theme-like argument). Depending on whether it is $\mathrm{T}$ or $\mathrm{R}$ that is treated like the monotransitive $\mathrm{P}$, we get two different non-neutral alignment patterns and a neutral pattern, shown in (2a-c). ${ }^{2}$ In Dryer's (1986) terminology, when $\mathrm{T}$ is treated like the monotransitive $\mathrm{P}$, we have a direct-object/indirect-object distinction. Renaming it to directive/indirective, as in (2a), makes the parallel to monotransitive alignment even clearer. (Usually the terms nominative/accusative and the terms ergative/absolutive are thought of as terms for linking patterns, not as terms for grammatical relations themselves.) And when $\mathrm{R}$ is treated like the monotransitive $\mathrm{P}$, we have a primary-object/secondary-object distinction. Again, for terminological convenience this has been renamed to primative/secundative in $(2 \mathrm{c}){ }^{3}$ We can now talk about indirectivity and secundativity in exactly the same way as we talk about accusativity and ergativity.

(2) The major ditransitive alignment types

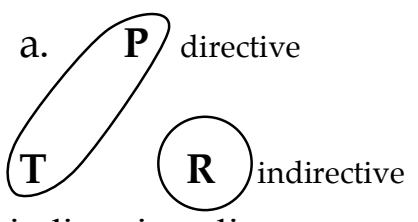

indirective alignment

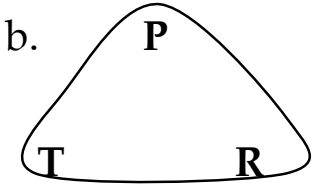

neutral alignment

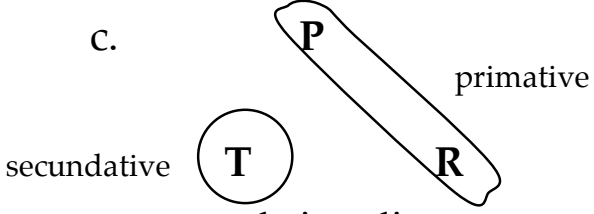

secundative alignment

Ditransitive alignment has received relatively little attention after Dryer (1986) in the typological literature, but I believe that it is quite instructive to study ditransitive alignment in the same general perspective in which monotransitive alignment has been studied.

In this paper, I will confine myself to overt argument marking, ignoring constituent order and more complex syntactic behavior. Argument marking is of two types: flagging on the arguments (= coding by case affixes and adpositions), and indexing on or near the verb (= crossreferencing or agreement).

Some examples of different ditransitive alignment types are shown in (3)-(7). In these example pairs, the monontransitive example is preceded by "(m)", the ditransitive example is preceded by "(d)".

The first example is German, a typical Indo-European language with case-marking but lacking any object indexing. Thus, German shows indirective alignment of flagging (Dative case-marking of $\mathrm{R}$ as opposed to Accusative case-marking of $\mathrm{T}$ and $\mathrm{P}$ ) and neutral alignment of indexing.

(3) German: indirective flagging, neutral indexing

(m) Der Junge füttert den Teddy ${ }_{A C C}$.

'The boy is feeding the teddy bear.'

(d) Der Junge gibt dem Teddy $y_{D A T}$ etwas $_{A C C} z$ u trinken.

'The boy is giving the teddy bear something to drink.'

the same as "ditransitive predicate", because placement verbs like put ('A puts B in C') are also three-place, like give ('A gives $\mathrm{B}$ to $\mathrm{C}^{\prime}$ ), but they are not ditransitive.

${ }^{2}$ The term alignment seems to be due to Plank (1979:4). It has been widely used only for the monotransitive accusative/ergative contrast of (1), but its extension to ditransitive alignment in this paper seems to be unproblematic.

${ }^{3}$ These should be pronounced ['praimətiv] and [si'kındətiv], respectively. 
In the richly head-marking Choctaw (Muskogean; United States), by contrast, there is no flagging of objects, but the person-number indices for the $\mathrm{R}$ argument differ from those for the $\mathrm{T}$ and $\mathrm{P} .{ }^{4}$ Thus, Choctaw shows neutral alignment of flagging and indirective aligment of indexing.

(4) Choctaw: neutral flagging, indirective indexing

(m) ofi-yat katos Ø-kopoli-tok dog-NOM cat 3.ACC-bite-PAST.3SG.NOM

'The dog bit the cat.'

(d) alla iskali im-a:-li-tok child money 3.DAT-give-1.NOM-PAST

'I gave money to the child.' (Davies 1986:16, 40)

Yoruba is a well-known case of a language with secundative alignment of flagging: It has a special preposition for secondary objects $\left(l^{\prime}\right.$ in $\left.5 \mathrm{~d}\right)$, while the $\mathrm{R}$ and $\mathrm{P}$ are unmarked. There is no indexing, so the alignment is neutral.

(5) Yoruba: secundative flagging, neutral indexing

(m) ó pa mí

he kill me

'He killed me.'

(d) ó fún mi l' ówó

he give me SEC money

'He gave me money.' (Rowlands 1969:21)

An example of a language with secundative indexing is Huichol (Uto-Aztecan; Mexico). In (6m), the object prefix wa- indexes the P, while in (6d) it indexes the R. There is no (i.e. neutral) flagging.

(6) Huichol: neutral flagging, secundative indexing

(m) Uukaraawiciiż tïri me-wa-zeiya. women children 3PL.NOM-3PL.PRIM-see

'The women see the children.'

(d) Nee tumiini uukari ne-wa-ruzeiyastia.

I money girls 1SG.NOM-3PL.PRIM-show

'I showed the money to the girls.' (Comrie 1982:99, 108)

In Hyow (Tibeto-Burman; Bangladesh) we find indirective flagging (the locative case-clitic $=a$ that is found only on the $\mathrm{R}$ ) and secundative indexing: We see that the verb indexes the $\mathrm{R}$ (in $7 \mathrm{~d}$ ) in the same way as it indexes the $\mathrm{P}$ in $(7 \mathrm{~m})$. ( 20 - and $2 e$ - are morphophonological variants of each other).

\footnotetext{
${ }^{4}$ I use the term index for a dependent person marker, following Lazard (1994).
} 
(7) Hyow: indirective flagging, secundative indexing

(m) yontura uy=la key Po-yo?wey-so
yesterday dog=ERG I 1SG.P-bite-CONCL
'Yesterday a dog bit me.'

(d) $c u=l a \quad k e y=a$ co Pe-pek

he=ERG I=LOC book 1SG.R-give

'He gave me a book.' (Peterson 2003: 174, 179)

In addition to the three major alignment types, there is a fourth simple type, tripartite alignment, in which all three role prototypes are treated differently from each other. This type also occurs in both monotransitive and ditransitive constructions, but it is very rare and will not be discussed further here (it is distinguished in Tables 1 and 3-6 below). Furthermore, monotransitive alignment studies usually distinguish a "(stative-)active" (or "semantically aligned") type, in which the $\mathrm{S}$ role is not treated uniformly: Some instances of $\mathrm{S}$ ("S $\mathrm{S}_{\mathrm{A}}$ ") pattern with the A, while others ("S") pattern with the P. Siewierska (2004:59) discusses the possibility of making an analogous distinction in ditransitive constructions. For the sake of simplicity, semantic alignment is disregarded for this study.

\section{The cross-linguistic study}

I will now present the results of a systematic study of ditransitive alignment patterns (both flagging and indexing) in a sample of 100 languages from all over the world (see the big table in the Appendix for a list of these languages). Each language is from a different genus (see Dryer 2005 for a list of genera), i.e. a genealogical group that is roughly at the same level of time depth as the subfamilies of Indo-European (perhaps 3500-4000 years). If ditransitive constructions are not older than that, each genus represents an independent case from the point of view of genealogical relatedness (admittedly we do not know whether this is really the case). From the point of view of areal relatedness, we know that many genera are not independent, because ditransitive alignment shows clear world-wide geographical patterns (see Haspelmath 2005). For example, in most of Eurasia (except for Southeast Asia), the indirective alignment type is the only attested type. When there are large linguistic areas of this kind, it is not possible to define a sample of languages that is truly representative (see Dryer 1989). This means that we have to be careful in drawing conclusions from any numbers that result from the world-wide study. But it still seems to me that such a study is of value, if only because it gives us an overview of the kinds of phenomena that we find in the world's languages. I will succumb to the temptation of suggesting further possible conclusions in the following sections, but the reader should be aware that these conclusions cannot be more than tentative.

In some languages, different ditransitive verbs are used with different flagging and indexing constructions. In order to make the cross-linguistic data comparable, I restrict my attention to the construction of the verb 'give'. Grammars usually contain information on a verb that is glossed as 'give', and this meaning seems to be fairly easy to identify across languages (see Newman 1996). 'Give' also seems to be the most frequent ditransitive verb in most languages. 
Moreover, I mostly focused on the patterning of full noun phrases and independent pronouns, rather than dependent pronouns (which often behave differently). ${ }^{5}$ Dependent person forms are considered here only if they cooccur with full noun phrases/independent pronouns.

In Table 1A-B, I give some figures showing the distribution of the ditransitive alignment types in the sample.

Table 1A. Flagging ${ }^{6}$

\begin{tabular}{|l|l|}
\hline alignment & $\#$ of lgs. \\
\hline indirective & 58 \\
\hline secundative & 6 \\
\hline neutral & 45 \\
\hline tripartite & 1 \\
\hline
\end{tabular}

Table 1B. Indexing

\begin{tabular}{|l|l|}
\hline alignment & \# of lgs. \\
\hline indirective & 16 \\
\hline secundative & 22 \\
\hline neutral & 71 \\
\hline tripartite & 1 \\
\hline
\end{tabular}

We see two striking differences between flagging and indexing. On the one hand, neutral alignment is much more frequent than nonneutral alignment in indexing, whereas neutral flagging is less common than nonneutral flagging. On the other hand, while indirective and secundative alignment are both common in indexing, in flagging only indirective alignment is at all common. Secundative flags (the type represented by Yoruba, see example (5)) are rare. The rarest type is the tripartite type. These asymmetries seem not to be accidental, and they call for an explanation. But first let us look at possible correlations between monotransitive and ditransitive alignment.

\section{On possible monotransitive/ditransitive correlations}

From the way in which the diagrams in (1) and (2) have been presented, one might expect that accusative alignment should go together with indirective alignment, and secundative alignment should go together with ergative alignment. I should stress that the left-to-right arrangement of A and $\mathrm{P}$ in (1) and $\mathrm{T}$ and $\mathrm{R}$ in (2) is not intended to have any significance. Still, Siewierska (2004:57) suggests that $\mathrm{T}$ is semantically closer to $\mathrm{P}$ than $\mathrm{R}$ is, just as A is semantically closer to $\mathrm{S}$ than $\mathrm{P}$ is. From this point of view, a correlation between accusativity and indirectivity on the one hand, and between ergativity and secundativity on the other, would make sense.

I looked at both ditransitive and monotransitive argument marking (flagging and indexing) in the 100 languages of the sample, so we can examine possible correlations between monotransitive alignment and ditransitive alignment. The resulting figures (together with one exemplifying language for each combination) are given in Table 2A-B, where I have again listed flagging and indexing separately. The rare tripartite type is omitted from this table.

\footnotetext{
${ }^{5}$ Full NPs sometimes show splits, too. The most common instance of such a split (and the only one relevant for the sample) is differential object marking, i.e. an accusative pattern with certain salient NPs in P role (animates, definites) and a neutral pattern with all other NPs. Such cases were classified as accusative here (thus minimizing the occurrence of neutral pattterns). However, for determining ditransitive alignment, I decided to compare the coding of $\mathrm{T}$ and $\mathrm{R}$ to the coding of non-salient Ps, because these are the most typical Ps.

${ }^{6}$ The numbers add up to 110 because 10 languages have two different ditransitive constructions and were counted twice.
} 
Table 2A. Flagging

\begin{tabular}{|l|l|l|l|}
\hline $\begin{array}{l}\text { mono- } \\
\text { tr. }\end{array}$ & $\begin{array}{l}\text { di- } \\
\text { trans. }\end{array}$ & $\begin{array}{l}\text { \# of } \\
\text { lgs. }\end{array}$ & $\begin{array}{l}\text { example } \\
\text { language }\end{array}$ \\
\hline ACC & IND & 18 & Arabic (Cl.) \\
ACC & SEC & 0 & -- \\
ACC & NEUT & 10 & Martuthunira \\
\hline ERG & IND & 12 & Lezgian \\
ERG & SEC & 2 & W Greenlandic \\
ERG & NEUT & 6 & Wambaya \\
\hline NEUT & IND & 27 & French \\
NEUT & SEC & 3 & Yoruba \\
NEUT & NEUT & 28 & Vietnamese \\
\hline
\end{tabular}

Table 2B. Indexing

\begin{tabular}{|l|l|l|l|}
\hline $\begin{array}{l}\text { mono- } \\
\text { tr. }\end{array}$ & $\begin{array}{l}\text { di- } \\
\text { trans. }\end{array}$ & $\begin{array}{l}\text { \# of } \\
\text { lgs. }\end{array}$ & $\begin{array}{l}\text { example } \\
\text { language }\end{array}$ \\
\hline ACC & IND & 8 & Choctaw \\
ACC & SEC & 15 & Hyow \\
ACC & NEUT & 28 & German \\
\hline ERG & IND & 4 & Abkhaz \\
ERG & SEC & 0 & -- \\
ERG & NEUT & 3 & Semelai \\
\hline NEUT & IND & 0 & -- \\
NEUT & SEC & 0 & -- \\
NEUT & NEUT & 29 & Cantonese \\
\hline
\end{tabular}

The figures are mostly quite close to what one would expect by chance. The only clear deviation from the expected frequencies is in neutral indexing, where languages with neutral monotransitive alignment always also have neutral ditransitive alignment (see the last three lines of Table 2B). ${ }^{7}$ Indirective or secundative indexing is not found at all in these languages. The explanation is that neutral indexing almost always means absence of indexing, and it is not surprising that when there is no indexing in monotransitive clauses, there is no indexing in ditransitive clauses either. It has long been known that "object agreement" by and large implies "subject agreement" (Moravcsik 1974, Givón 1976; see Siewierska 2004:133ff. for dicussion), and if this is true, then a fortiori one would not expect languages that lack indexing in monotransitive clauses to show indexing for the $\mathrm{R}$ or $\mathrm{T}$ argument of ditransitive clauses.

There are two other empty cells in the table, but it is doubtful that they are significant. First, the sample includes languages with accusative monotransitive flagging and secundative ditransitive flagging, but this is expected since secundative flagging is rare anyway. And I am aware of two languages of this type that happened not to make it into my sample, Kunama and Yokuts. The other zero in Table 2, representing the absence of a language with ergative monotransitive and secundative ditransitive indexing, might just possibly represent a real tendency for ergative indexing to correlate with indirective indexing. But since there are only seven languages with ergative indexing in the sample, this could be an accidental gap as well.

Thus, by and large it appears that the ditransitive alignment type a language chooses is independent of its monotransitive alignment type.

\section{Flagging/indexing asymmetries}

Let us now go on to compare alignment in flagging with alignment in indexing, and we will do this both for monotransitive and for ditransitive alignment. The basic data are given in Table 3A$\mathrm{B}$ and Table 4A-B. We already saw Table 4A-B, which is identical to Table 1A-B. Here it is repeated for better comparison with the data on monotransitive alignment in Table $3 \mathrm{~A}-\mathrm{B}$.

\footnotetext{
${ }^{7}$ Siewierska (2003:357) and (2004:137) discusses possible exceptions to this generalization.
} 
Table 3. Monotransitive

A. Flagging
\begin{tabular}{|l|l|}
\hline ACC & 29 \\
\hline ERG & 19 \\
\hline NEUT & 49 \\
\hline TRIP & 3 \\
\hline
\end{tabular}

B. Indexing

\begin{tabular}{|l|l|}
\hline ACC & 48 \\
\hline ERG & 7 \\
\hline NEUT & 33 \\
\hline TRIP & 12 \\
\hline
\end{tabular}

Table 4. Ditransitive

A. Flagging
\begin{tabular}{|l|l|}
\hline IND & 58 \\
\hline SEC & 6 \\
\hline NEUT & 45 \\
\hline TRIP & 1 \\
\hline
\end{tabular}

B. Indexing
\begin{tabular}{|l|l|}
\hline IND & 16 \\
\hline SEC & 22 \\
\hline NEUT & 71 \\
\hline TRIP & 1 \\
\hline
\end{tabular}

The comparison leads to two rather striking observations concerning a difference between monotransitive and ditransitive constructions that would not be immediately expected. They are expressed in the following two generalizations, which are mirror images of each other.

\section{Generalization 1:}

In monotransitive constructions, flagging shows no strong alignment preference (29 ACC: 19 ERG), but indexing strongly prefers accusative alignment (48 ACC: 7 ERG).

\section{Generalization 2:}

In ditransitive constructions, indexing shows no strong alignment preference (16 IND: 22 SEC), but flagging strongly prefers indirective alignment (58 IND: 6 SEC).

Even though we said above that in view of the non-representativeness of the sample and the lack of independence of the individual cases we cannot draw firm conclusions from the numbers, it seems plausible that the preponderance of accusative indexing and the preponderance of indirective flagging is not an accident. We probably cannot assign much significance to the difference between 29 cases of accusative flagging and 19 cases of ergative flagging, but the difference between 48 cases of accusative indexing and 7 cases of ergative indexing is on a different order of magnitude. So in the following I will propose explanations for these observations. These explanations all appeal to regularities of language change, in the spirit of Bybee (1988, 2003).

The easiest to explain is Generalization 1, the preference for accusative over ergative indexing: When case-marked personal pronouns become verbal indices, this generally results in accusative alignment because personal pronouns tend to have accusative alignment even in languages whose flagging is otherwise aligned ergatively (this is known as NP split ergativity, cf. Dixon 1994:ch. 4). And when personal pronouns with no case-marking become verbal indices, there is also a very strong tendency for the resulting indexing patterns to be aligned accusatively, because agreement markers arise in topicalization constructions (see Givón 1976), and the S and the A are the most topicworthy role-types.

This explanation also extends to ditransitive indexing, as Givón (1976) already pointed out: The Recipient is more topicworthy than the Theme, so we expect secundative indexing to be much more common than indirective indexing. This is perhaps confirmed by the data (we find 22 languages with secundative indexing, as against 16 languages with indirective indexing), but at most we have a weak preference here. Why should this be the case? Why is ditransitive indexing roughly symmetrical (as stated in Generalization 2), and why are there so many languages with indirective indexing?

I would like to suggest that there is again a diachronic explanation for this. It seems that ditransitive constructions are often innovated, that they are much less conservative on the whole than monotransitive constructions. This is not surprising, because all languages have far fewer 
ditransitive verbs than monotransitive verbs, so it is easier for a new pattern to spread across the whole domain. By far the most important source for new ditransitive constructions seems to be metaphorical modeling on the spatial transfer situation, where in general the theme is treated as the $\mathrm{P}$ and the directional argument is some kind of oblique argument.

A new ditransitive construction of this type will therefore show a strong tendency to have both indirective flagging and indirective indexing. We can observe a change of this kind happening in Lango at the moment. Lango has subject and object agreement in monotransitive constructions, and in the old ditransitive construction in (8b) the object agreement is with the Recipient, i.e. this construction is aligned secundatively. In the new ditransitive construction in (8c), which marks the recipient with the oblique preposition bot, the indexing and flagging alignment is indirective.

(8) Lango (Noonan 1992:120-121, 149)

a. monotransitive object indexing

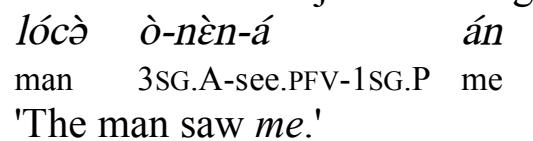

b. old ditransitive construction, with $\mathrm{P}=\mathrm{R}$ indexing

lócò ò-mìy-á búk

man 3SG.A-give.PFV-1SG.R book

'The man gave me the book.'

c. new ditransitive construction, with $\mathrm{P}=\mathrm{T}$ indexing
lóc̀̀ ò-mìy-ć bòt-á
man 3SG.A-give.PFV-3SG.P to-1SG
'The man gave him (e.g. a slave) to me.'

This diachronic explanation also accounts for the fact that indirective flagging is so common (Generalization 2; recall that 58 languages have indirective flagging as opposed to just 6 languages with secundative flagging). An additional reason for the rarity of secundative flagging, compared to the high frequency of accusative flagging, is probably the absence of other diachronic sources for secundative flagging. It seems that accusative flagging often arises from the generalization of differential case-marking of animate and definite direct objects (Lehmann 1995:110). However, ditransitive Themes are very rarely animate or definite and hence would hardly ever show differential case-marking. So again this is a diachronic explanation that presupposes that one type of change is more frequent than another type of change, and although I have no direct evidence for this claim, I believe that it is a plausible hypothesis.

So far we have only looked at asymmetries in the non-neutral alignment types. but neutral alignment also shows interesting asymmetries:

\section{Generalization 3:}

In monotransitive constructions, neutral flagging is more common than neutral indexing $(49: 33)$. 


\section{Generalization 4:}

In ditransitive constructions, neutral indexing is more common than neutral flagging (71:45).

Why should we find such an asymmetry of neutral alignment? First of all, we must note that neutral flagging and neutral indexing is always zero in monotransitive clauses, and it is zero in the great majority of ditransitive clauses (see Tables 5-6 in the next section).

Let us first look at Generalization 3 about neutral flagging, which implies that $\mathrm{A}$ and $\mathrm{P}$ are much more often zero-coded than $\mathrm{R}$ and $\mathrm{T}$. One explanation would simply say that the argument types that occur in monotransitive clauses are much more frequent than those that occur in ditransitive clauses, so they are more predictable and overt coding is more dispensable (see Haspelmath (to appear) for the pervasive role of frequency and predictability in shaping grammatical asymmetries). An additional reason might be that flagging is often redundant in monotransitive clauses because word order can unambiguously signal semantic roles: In verbmedial languages, if we just hear a verb and an argument, we can immediately identify the argument's role (cf. Greenberg 1963, Siewierska 1996). This is much more rarely the case in ditransitive alignment because there are very few languages where Recipient and Theme occur on different sides of the verb, so this, too, favors unique marking and hence flagging in ditransitive clauses.

The explanation for Generalization 4 (which derives from the predominance of zero indexing in ditransitives) is quite straightforward: Because indexing is linked to topicworthiness, as Givón 1976 has shown, it is far more common with subjects than with objects, and hence far more common in monotransitive clauses.

\section{Overt coding vs. zero-coding of arguments: Coding types}

\subsection{Coding types}

So far we have primarily examined the abstract alignment patterns and have said little about ways of overtly coding arguments. In this section, we look at coding types, i.e. the distribution of overt markers vs. the absence of markers. Each alignment type corresponds to several different coding types. In the following, I use schematic representations for coding types in which " $m$ " stands for "marked, overtly coded", and "0" stands for "zero-coded". Accusative alignment can have the coding types $\mathrm{S}=0, \mathrm{~A}=0, \mathrm{P}=\mathrm{m}$ (where $\mathrm{S} / \mathrm{A}$ is zero-coded and there is an overt accusative case), $\mathrm{S}=\mathrm{m}, \mathrm{A}=\mathrm{m}, \mathrm{P}=0$ (where $\mathrm{P}$ is zero-coded, contrasting with an overtly "marked nominative"), and $\mathrm{S}=\mathrm{m}, \mathrm{A}=\mathrm{m}, \mathrm{P}=\mathrm{m}$ (where both the nominative and the accusative are overtly, but differently, coded). The three types are shown in tabular format and with pseudoEnglish examples in (9). "00m" is short for "S=0, $A=0, P=\mathrm{m}$ ", and so on. 
(9) accusative monotransitive coding types
A zero-coded (0)
$\mathrm{P}$ overtly coded (m)
a. $00 \mathrm{~m}=\mathrm{S} \quad$ zero-coded $(0)$
Guest- $\varnothing$ arrived.
Girl-Ø saw boy-M.
("economical pattern", e.g. Hungarian)
b. $\mathbf{m m 0}=\mathrm{S} \quad$ overtly coded $(\mathrm{m})$
A overtly coded $(\mathrm{m})$
$\mathrm{P}$ zero-coded (0)
Guest-M arrived.
Girl-M saw boy-Ø.
("marked-nominative pattern", e.g. Maricopa)
c. $\mathbf{m m m}=\mathrm{S} \quad$ overtly coded $(\mathrm{m})$
A overtly coded (m)
$\mathrm{P}$ overtly coded (m)
Guest-M arrived
Girl-M saw boy-M.
("explict pattern", e.g. Japanese)

I use an analogous schematic representation pattern for ditransitive coding types. "00m" stands for $" \mathrm{P}=0, \mathrm{~T}=0, \mathrm{R}=\mathrm{m}$ ", and so on. Two exemplary coding types are shown in tabular format in (10).

(10) ditransitive (P-T-R):
a. $\mathbf{0 0 m}=\mathrm{P} \quad$ zero-coded $(0)$
$X$ saw boy- $\varnothing$.
$\mathrm{T}$ zero-coded (0)
$\mathrm{R}$ overtly coded (m)
$X$ gave book-Ø girl-M.
("economical pattern", e.g. English)
b. $\mathbf{m m m}=\mathrm{P} \quad$ overtly coded $(\mathrm{m})$
$\mathrm{T}$ overtly coded (m)
$\mathrm{R}$ overtly coded (m)
("explicit pattern", e.g. Japanese)

\author{
$X$ saw boy- $M$. \\ $X$ gave book- $M$ girl- $M$.
}

Let us now look at the distribution of the coding types in the languages of the sample.

\subsection{Coding types in flagging}

Table 5 shows the distribution of the distribution of the above coding types over the alignment types in the languages of the sample. 
Table 5. Coding types in flagging

A. Monotransitive

\begin{tabular}{|l|l|l|l|}
\hline $\begin{array}{l}\text { align } \\
\text { ment }\end{array}$ & $\begin{array}{l}\text { coding } \\
\text { type }\end{array}$ & $\begin{array}{l}\text { \# } \\
\text { of } \\
\text { lgs }\end{array}$ & $\begin{array}{l}\text { example } \\
\text { language }\end{array}$ \\
\hline \multirow{2}{*}{$\begin{array}{l}\text { ACC } \\
(29)\end{array}$} & $00 \mathrm{~m}$ & 21 & Hungarian \\
\cline { 2 - 4 } & $\mathrm{mm} 0$ & 3 & Maricopa \\
\cline { 2 - 4 } & $\mathrm{mmm}$ & 5 & Japanese \\
\hline \multirow{2}{*}{$\begin{array}{l}\text { ERG } \\
(19)\end{array}$} & $0 \mathrm{~m} 0$ & 15 & Lezgian \\
\cline { 2 - 4 } & $\mathrm{m} 0 \mathrm{~m}$ & 0 & -- \\
\cline { 2 - 4 } & $\mathrm{mmm}$ & 4 & Wardaman \\
\hline \multirow{2}{*}{$\begin{array}{l}\text { NEUT } \\
(49)\end{array}$} & 000 & 49 & English \\
\cline { 2 - 4 } & $\mathrm{mmm}$ & 0 & -- \\
\hline TRIP (3) & $0 \mathrm{~mm}$ & 3 & Sahaptin \\
\hline
\end{tabular}

\section{B. Ditransitive}

\begin{tabular}{|l|l|l|l|}
\hline $\begin{array}{l}\text { align } \\
\text { ment }\end{array}$ & $\begin{array}{l}\text { coding } \\
\text { type }\end{array}$ & $\begin{array}{l}\# \\
\text { of } \\
\text { lgs }\end{array}$ & \\
\hline \multirow{2}{*}{$\begin{array}{l}\text { IND } \\
(58)\end{array}$} & $00 \mathrm{~m}$ & 39 & French \\
\cline { 2 - 4 } & $\mathrm{mm} 0$ & 0 & -- \\
\cline { 2 - 4 } & $\mathrm{mmm}$ & 19 & Hungarian \\
\hline \multirow{2}{*}{$\begin{array}{l}\text { SEC } \\
(6)\end{array}$} & $0 \mathrm{~m} 0$ & 4 & Yoruba \\
\cline { 2 - 4 } & $\mathrm{m} 0 \mathrm{~m}$ & 1 & Sahaptin \\
\cline { 2 - 4 } & $\mathrm{mmm}$ & 1 & Tagalog \\
\hline \multirow{2}{*}{$\begin{array}{l}\text { NEUT } \\
(45)\end{array}$} & 000 & 34 & Huichol \\
\cline { 2 - 4 } & $\mathrm{mmm}$ & 11 & Martuthunira \\
\hline TRIP (1) & $\mathrm{m} 0 \mathrm{~m}$ & 1 & Awa Pit \\
\hline
\end{tabular}

The first generalization that emerges from these figures is one that has often been observed for monotransitive alignment, less often for ditransitive alignment:

\section{Generalization 5: Economical Flagging}

In non-neutral alignment, the overwhelming preference in flagging is for the specially treated role to be overtly coded, and for the two equally treated roles to be zero-coded. The opposite case (specially treated role zero-coded, equally treated role overtly coded) is very rare.

Let us take a closer look at the individual figures, beginning with flagging in monotransitive structures. In accusative alignment, there are 21 languages with coding type $00 \mathrm{~m}$ (the "economical" type), where the specially treated role (the $\mathrm{P}$ ) is overtly coded, and the S and A are zero-coded. The opposite coding type mm0, with overt ("marked nominative") coding of the equally treated roles, occurs only three times in my sample (Maricopa, Berber, and Oromo).

In ergative alignment, the corresponding figures are 15 and 0 . Out of the 19 languages with ergative flagging, 15 have the preferred coding type in which the $\mathrm{A}$ is overtly coded and $\mathrm{S} / \mathrm{P}$ are zero-coded. There are no "marked absolutive" languages in the sample. Dixon (1994:67) stated that such constructions appear not to occur, and in any event they are very rare. ${ }^{8}$

In ditransitive structures, the situation is completely parallel: In indirective alignment, 39 languages have the coding type $00 \mathrm{~m}$, where the $\mathrm{R}$ is overtly coded and the $\mathrm{T}$ and $\mathrm{P}$ are zerocoded. An example is (7) from Hyow, and also the English prepositional to construction. However, no language has the opposite coding type (there are no "unmarked-dative" languages). This may be an absolute universal, as I am not aware of any language outside the sample with this coding type.

Similarly, in secundative alignment, there are four $0 \mathrm{~m} 0$ languages which like Yoruba have an overtly coded T, with zero-coded P/R, while only one language, Sahaptin, has the opposite pattern (with a zero-coded $\mathrm{T}$ and overtly coded $\mathrm{P}$ and $\mathrm{R}$ ), which can be called "marked primative".

\footnotetext{
8 Two languages that have recently been described as "marked absolutive" are Nias, a Western Austronesian language (Brown 2005), and Tlapanec, an Otomanguean language (Wichmann 2005).
} 
(11) Marked primative in Sahaptin (Rude 1997:324, 334)
(m) i-q'ínun-a twínš ṫniit-na
3.NOM-see-PAST man house-PRIM
'The man saw the house.'
(d) pa-ní-ya k'úsi miyúux-na
3PL.NOM-give-PAST horse chief-PRIM
'They gave the horse to the chief.'

The quantitative asymmetries of coding types are summarized in (12).

(12) monotransitive flagging/accusative alignment:

monotransitive flagging/ergative alignment: 15:0

ditransitive flagging/indirective alignment: 39:0

ditransitive flagging/secundative alignment: $4: 1$
21:3 (00m:mm0)

$(0 \mathrm{~m} 0: \mathrm{m} 0 \mathrm{~m})$

$(00 \mathrm{~m}: \mathrm{mm} 0)$

$(0 \mathrm{~m} 0: \mathrm{m} 0 \mathrm{~m})$

The explanation for this striking observation is obvious and was pointed out by Comrie (1978) for ergative alignment: The coding types in which the specially treated role is overtly coded are more economical than all others, because the two equally treated roles will always be more frequent and hence should be zero-coded. Thus, a very simple economy consideration explains the coding types of flagging not only in monotransitive structures, but also in ditransitive structures.

\subsection{Coding types in indexing}

Table 6 shows the distribution of the distribution of the above coding types over the alignment types in the languages of the sample.

Table 6. Coding types in indexing

A. Monotransitive

\begin{tabular}{|c|c|c|c|}
\hline $\begin{array}{l}\text { align } \\
\text { ment }\end{array}$ & $\begin{array}{l}\text { coding } \\
\text { type }\end{array}$ & $\begin{array}{l}\# \\
\text { of } \\
\text { lgs }\end{array}$ & $\begin{array}{l}\text { example } \\
\text { language }\end{array}$ \\
\hline \multirow{3}{*}{$\begin{array}{l}\text { ACC } \\
(48)\end{array}$} & $00 \mathrm{~m}$ & 1 & Khoekhoe \\
\hline & $\mathrm{mm} 0$ & 24 & Turkish \\
\hline & $\mathrm{mmm}$ & 23 & Choctaw \\
\hline \multirow{3}{*}{$\begin{array}{l}\text { ERG } \\
\text { (7) }\end{array}$} & $0 \mathrm{~m} 0$ & 2 & Semelai \\
\hline & $\mathrm{m} 0 \mathrm{~m}$ & 1 & Kipeá \\
\hline & $\mathrm{mmm}$ & 4 & Tzutujil \\
\hline \multirow{2}{*}{$\begin{array}{l}\text { NEUT } \\
\text { (33) }\end{array}$} & 000 & 33 & Japanese \\
\hline & $\mathrm{mmm}$ & 0 & -- \\
\hline $\operatorname{TRIP(12)}$ & $\mathrm{mmm}$ & 12 & Wambaya \\
\hline
\end{tabular}

B. Ditransitive

\begin{tabular}{|l|l|l|l|}
\hline $\begin{array}{l}\text { align } \\
\text { ment }\end{array}$ & $\begin{array}{l}\text { coding } \\
\text { type }\end{array}$ & $\begin{array}{l}\# \\
\text { of } \\
\text { lgs }\end{array}$ & example language \\
\hline \multirow{2}{*}{$\begin{array}{l}\text { IND } \\
(16)\end{array}$} & $00 \mathrm{~m}$ & 0 & -- \\
\cline { 2 - 4 } & $\mathrm{mm} 0$ & 10 & Tzutujil \\
\cline { 2 - 4 } & $\mathrm{mmm}$ & 6 & Choctaw \\
\hline \multirow{2}{*}{$\begin{array}{l}\text { SEC } \\
(22)\end{array}$} & $0 \mathrm{~m} 0$ & 0 & -- \\
\cline { 2 - 4 } & $\mathrm{m} 0 \mathrm{~m}$ & 22 & Hyow \\
\cline { 2 - 4 } & $\mathrm{mmm}$ & 0 & -- \\
\hline NEUT & 000 & 68 & English \\
$(71)$ & $\mathrm{mmm}$ & 3 & Lakhota \\
\hline TRIP (1) & $\mathrm{mmm}$ & 1 & Imonda \\
\hline
\end{tabular}

Two generalizations about the coding patterns of ditransitive indexing emerge from this table. 


\section{Generalization 6:}

Indirective indexing is never achieved by indexing of the $\mathrm{R}$ alone (only by indexing of $\mathrm{P}$ and $\mathrm{T}$ alone, or by differential indexing of $\mathrm{R}$ ).

So we have indirectively indexing languages like Choctaw (see example 4 above), where there is a special "dative" person prefix, and languages like Tzutujil, where only the directive argument ( $\mathrm{P}$ and $\mathrm{T})$, but not the indirective argument $(\mathrm{R})$, is indexed on the verb (the index is zero in both sentences in 13):

(13) Tzutujil

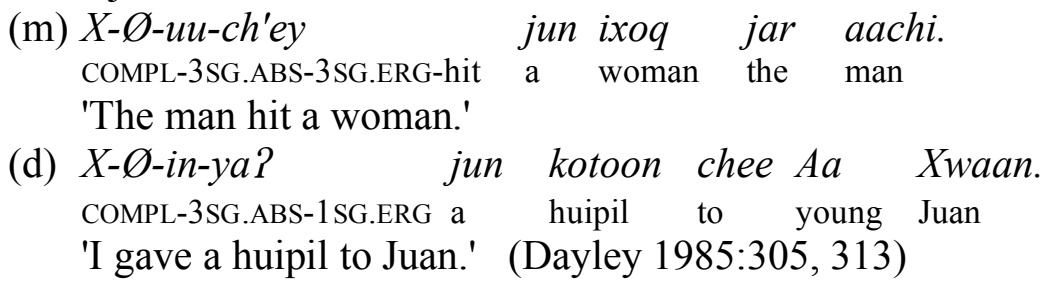

As we saw in $\S 4$, the $\mathrm{R}$ is more topicworthy than the $\mathrm{T}$, and indexing typically arises in topicalization constructions. Thus, one might expect the " $00 \mathrm{~m}$ " pattern, with indexing of the $\mathrm{R}$ alone, to come up. However, there are always at least some Ps that are also animate and hence topicworthy, so it seems that at least some indexing of $\mathrm{P}$ is always found when $\mathrm{R}$ is indexed. A language that comes close to being an exception to Generalization 6 is Spanish, where indexing by preverbal person clitics is generally found with full NP Recipients (11a), but is not used with Patients (11b) (in 11a, le is optional but strongly preferred):

(14) Spanish (Parodi 1998:86-89)

a. (Le) doy la carta a un vecino.

'I give the lettter to a neighbor.'

b. (*La) veo a la mujer.

'I see the woman.'

c. La veo a ella.

(*Veo a ella.)

'I see HER.'

d. Le doy la carta a él.

'I give the letter to him.'

(*Doy la carta a él.)

However, Spanish requires indexing with the most salient $\mathrm{P}$ and $\mathrm{R}$ arguments, independent person forms, as shown in (11c-d). Thus, since such splits were ignored for the classification in Table 6, Spanish would count as "mmm" (the Choctaw type), but its pattern is unusual (though it should be noted that non-standard varieties of Spanish often extend the indexing of $\mathrm{P}$ to full NPs and allow La veo a la mujer; see Parodi 1998).

The second generalization about ditransitive indexing patterns in Table 6 is the following: 


\section{Generalization 7:}

Secundative indexing is always achieved by indexing of the $\mathrm{P}$ and $\mathrm{R}$ alone, never by indexing of $\mathrm{T}$ alone or by differential indexing of $\mathrm{T}$.

Thus, all languages with secundative indexing are like Huichol and Hyow (examples 6 and 7) in indexing only the primative argument ( $\mathrm{P}$ and $\mathrm{R}$ ), lacking any indexing of the secundative argument (the $\mathrm{T}$ ). The reason for this is again the low prominence (and lack of topicworthiness) of the $\mathrm{T}$ argument: Indexing of $\mathrm{T}$ alone is of course excluded, and differential indexing of $\mathrm{T}$ is unlikely for the same reason.

\section{Conclusions}

This paper has examined certain aspects of ditransitive alignment types and their coding in a sample of 100 languages, comparing them with monotransitive alignment types. While no correlations between monotransitive alignment types and ditransitive alignment types are found, a number of asymmetries in cross-linguistic frequency distribution can be observed that seem to call for explanations. I have provided such tentative explanations, often based on greater or lesser likelihood of certain diachronic changes. These explanations are not particularly surprising, and some of them have been known for three decades or more. What is new here is primarily the systematic comparison of ditransitive and monotransitive alignment types, as well as the fairly thorough documentation (for indexing, Siewierska (2004: ch. 4) is based on a significantly larger sample, but she does not document it in detail).

\section{Abbreviations

$\begin{array}{ll}\text { CONCL } & \text { conclusive } \\ \text { IND } & \text { indirective } \\ \text { NEUT } & \text { neutral } \\ \text { PRIM } & \text { primative } \\ \text { SEC } & \text { secundative } \\ \text { TRIP } & \text { tripartite }\end{array}$

The remaining abbreviations follow well-known conventions (see the Leipzig Glossing Rules, http://www.eva.mpg.de/lingua/files/morpheme.html). 


\section{Appendix:}

\section{Ditransitive and monotransitive alignment types and coding types in $\mathbf{1 0 0}$} languages

\begin{tabular}{|c|c|c|c|c|c|c|c|c|c|c|}
\hline & & & & & & \multirow{2}{*}{\multicolumn{4}{|c|}{ Monotransitive }} & \multirow[b]{4}{*}{ reference } \\
\hline \multirow{3}{*}{ language } & \multirow[b]{3}{*}{ genus (and family) } & \multicolumn{4}{|c|}{ Ditransitive } & & & & & \\
\hline & & \multicolumn{2}{|c|}{ alignment } & \multicolumn{2}{|l|}{ coding } & \multicolumn{2}{|c|}{ alignment } & \multicolumn{2}{|l|}{ coding } & \\
\hline & & $\begin{array}{l}\text { flag- } \\
\text { ging }\end{array}$ & $\begin{array}{l}\text { index } \\
\text {-ing }\end{array}$ & $\begin{array}{l}\text { flag- } \\
\text { ging }\end{array}$ & $\begin{array}{l}\text { index- } \\
\text { ing }\end{array}$ & $\begin{array}{l}\text { flag- } \\
\text { ging }\end{array}$ & $\begin{array}{l}\text { in- } \\
\text { dex- } \\
\text { ing }\end{array}$ & $\begin{array}{l}\text { flag- } \\
\text { ging }\end{array}$ & $\begin{array}{l}\text { index- } \\
\text { ing }\end{array}$ & \\
\hline \multicolumn{11}{|l|}{ Africa } \\
\hline $\begin{array}{l}\text { Arabic } \\
\text { (Classical) }\end{array}$ & Semitic (Afro-Asiatic) & ind & neut & $\mathrm{mmm}$ & 000 & acc & acc & $\mathrm{mmm}$ & $\mathrm{mm} 0$ & Fischer 1972 \\
\hline Bagirmi & $\begin{array}{l}\text { Bongo-Bagirmi (Nilo- } \\
\text { Saharan) }\end{array}$ & ind & ind & $00 \mathrm{~m}$ & $\mathrm{~mm} 0$ & neut & acc & 000 & $\mathrm{mmm}$ & Stevenson 1969 \\
\hline Coptic & Egyptian (Afro-Asiatic) & ind & neut & $\mathrm{mmm}$ & 000 & acc & acc & $00 \mathrm{~m}$ & $\mathrm{~mm} 0$ & Lambdin 1983 \\
\hline Dogon & Dogon (Niger-Congo) & ind & neut & $\mathrm{mmm}$ & 000 & acc & acc & $00 \mathrm{~m}$ & $\mathrm{~mm} 0$ & Plungian 1995 \\
\hline Hausa & West Chadic (Afroasiatic) & neut & neut & 000 & 000 & neut & acc & 000 & $\mathrm{~mm} 0$ & Newman 2000 \\
\hline $\mathrm{Ik}$ & Kuliak (Nilo-Saharan) & ind & neut & $\mathrm{mmm}$ & 000 & acc & acc & $00 \mathrm{~m}$ & $\mathrm{~mm} 0$ & Serzisko 1992 \\
\hline Jeli & $\begin{array}{l}\text { Western Mande (Niger- } \\
\text { Congo) }\end{array}$ & ind & neut & $00 \mathrm{~m}$ & 000 & neut & neut & 000 & 000 & Tröbs 1998 \\
\hline Kana & Cross-River (Niger-Congo) & neut & neut & 000 & 000 & neut & neut & 000 & 000 & Ikoro 1996 \\
\hline Kanuri & Saharan (Nilo-Saharan) & ind & neut & $\mathrm{mmm}$ & $\mathrm{m} 0 \mathrm{~m}$ & acc & acc & $00 \mathrm{~m}$ & $\mathrm{mmm}$ & Cyffer 1991 \\
\hline Kera & East Chadic (Afro-Asiatic) & ind & neut & $00 \mathrm{~m}$ & 000 & neut & neut & 000 & 000 & Ebert 1979 \\
\hline $\begin{array}{l}\text { Khoekhoe } \\
(=\text { Nama })\end{array}$ & Central Khoisan & neut & neut & $\mathrm{mmm}$ & $\mathrm{mmm}$ & acc & acc & $00 \mathrm{~m}$ & $00 \mathrm{~m}$ & Hagman 1977 \\
\hline Krongo & Kadugli & ind & neut & $00 \mathrm{~m}$ & 000 & neut & acc & 000 & $\mathrm{mm0}$ & Reh 1985 \\
\hline Lango I & \multirow[t]{2}{*}{ Nilotic (Nilo-Saharan) } & neut & $\mathrm{sec}$ & 000 & $\mathrm{~m} 0 \mathrm{~m}$ & \multirow[t]{2}{*}{ neut } & \multirow[t]{2}{*}{ acc } & \multirow[t]{2}{*}{000} & \multirow[t]{2}{*}{$\mathrm{mmm}$} & \multirow[t]{2}{*}{ Noonan 1992} \\
\hline Lango II & & ind & ind & $00 \mathrm{~m}$ & $\mathrm{~mm} 0$ & & & & & \\
\hline Noon & $\begin{array}{l}\text { Northern Atlantic (Niger- } \\
\text { Congo) }\end{array}$ & neut & neut & 000 & 000 & neut & neut & 000 & 000 & Soukka 2000 \\
\hline Oromo (Harar) & $\begin{array}{l}\text { Eastern Cushitic (Afro- } \\
\text { Asiatic) }\end{array}$ & ind & neut & $00 \mathrm{~m}$ & 000 & acc & acc & $\mathrm{mm} 0$ & $\mathrm{~mm} 0$ & Owens 1985 \\
\hline $\begin{array}{l}\text { Songhay (K. } \\
\text { Senni) I }\end{array}$ & \multirow[t]{2}{*}{ Songhay (Nilo-Saharan) } & ind & neut & $00 \mathrm{~m}$ & 000 & \multirow[t]{2}{*}{ neut } & \multirow[t]{2}{*}{ neut } & \multirow[t]{2}{*}{000} & \multirow[t]{2}{*}{000} & \multirow[t]{2}{*}{ Heath 1999} \\
\hline $\begin{array}{l}\text { Songhay (K. } \\
\text { Senni) II }\end{array}$ & & neut & neut & 000 & 000 & & & & & \\
\hline Supyire I & Gur (Niger-Congo) & ind & neut & $00 \mathrm{~m}$ & 000 & neut & neut & 000 & 000 & Carlson 1994 \\
\hline Supyire II & & neut & neut & 000 & 000 & & & & & \\
\hline $\begin{array}{l}\text { Tamazight (Ayt } \\
\text { Ndhir) }\end{array}$ & Berber (Afro-Asiatic) & ind & neut & $00 \mathrm{~m}$ & 000 & acc & acc & $\mathrm{mm} 0$ & $\mathrm{~mm} 0$ & Penchoen 1973 \\
\hline Yoruba & Defoid (Niger-Congo) & $\mathrm{sec}$ & neut & $0 \mathrm{~m} 0$ & 000 & neut & neut & 000 & 000 & Rowlands 1969 \\
\hline Zulu & Bantoid (Niger-Congo) & neut & $\sec$ & 000 & $\mathrm{~m} 0 \mathrm{~m}$ & neut & acc & 000 & $\mathrm{mmm}$ & $\begin{array}{l}\text { Ziervogel et al. } \\
1981\end{array}$ \\
\hline Eurasia & & & & & & & & & & \\
\hline Abkhaz & Abkhaz-Adyghean & neut & ind & 000 & $\mathrm{mmm}$ & neut & erg & 000 & $\mathrm{mmm}$ & Hewitt 1979 \\
\hline Ainu & Ainu & neut & neut & 000 & $\mathrm{mmm}$ & neut & trip & 000 & $\mathrm{mmm}$ & Shibatani 1990 \\
\hline $\begin{array}{l}\text { Armenian } \\
\text { (Eastern) }\end{array}$ & Armenian (Indo-European) & ind & neut & $\mathrm{mmm}$ & 000 & acc & acc & $00 \mathrm{~m}$ & $\mathrm{~mm} 0$ & Minassian 1980 \\
\hline Basque & Basque & ind & ind & $00 \mathrm{~m}$ & $\mathrm{mmm}$ & erg & erg & $0 \mathrm{~m} 0$ & $\mathrm{mmm}$ & Saltarelli 1988 \\
\hline Chukchi & Chukchi-Kamchatkan & ind & ind & $\mathrm{mmm}$ & $\mathrm{mm} 0$ & erg & trip & $\mathrm{mmm}$ & $\mathrm{mmm}$ & Dunn 1999 \\
\hline Dhivehi & Indic (Indo-European) & ind & neut & $00 \mathrm{~m}$ & 000 & neut & acc & 000 & $\mathrm{~mm} 0$ & $\begin{array}{l}\text { Cain \& Gair } \\
2000\end{array}$ \\
\hline English I & Germanic (Indo-European) & ind & neut & $00 \mathrm{~m}$ & 000 & neut & acc & 000 & $\mathrm{~mm} 0$ & personal \\
\hline English II & & neut & neut & 000 & 000 & & & & & knowledge \\
\hline French & Italic (Indo-European) & ind & neut & $00 \mathrm{~m}$ & 000 & neut & acc & 000 & $\mathrm{~mm} 0$ & $\begin{array}{l}\text { personal } \\
\text { knowledge }\end{array}$ \\
\hline Georgian & Kartvelian & neut & ind & $\mathrm{mmm}$ & $\mathrm{mmm}$ & acc & acc & $\mathrm{mmm}$ & $\mathrm{mmm}$ & Hewitt 1995 \\
\hline Hmong Njua & Miao-Yao & ind & neut & $00 \mathrm{~m}$ & 000 & neut & neut & 000 & 000 & $\begin{array}{l}\text { Harriehausen } \\
1990\end{array}$ \\
\hline Hungarian & Ugric (Uralic) & ind & ind & $\mathrm{mmm}$ & $\mathrm{mm} 0$ & acc & trip & $00 \mathrm{~m}$ & $\mathrm{mmm}$ & $\begin{array}{l}\text { Kenesei et al. } \\
1998\end{array}$ \\
\hline Japanese & Japanese & ind & neut & $\mathrm{mmm}$ & 000 & acc & neut & $\mathrm{mmm}$ & 000 & Shibatani 1990 \\
\hline Kannada & $\begin{array}{l}\text { Dravidian proper } \\
\text { (Dravidian) }\end{array}$ & ind & neut & $\mathrm{mmm}$ & 000 & acc & acc & $00 \mathrm{~m}$ & $\mathrm{~mm} 0$ & Sridhar 1989 \\
\hline
\end{tabular}




\begin{tabular}{|c|c|c|c|c|c|c|c|c|c|c|}
\hline Lezgian & $\begin{array}{l}\text { Lezgic (Nakh- } \\
\text { Daghestanian) }\end{array}$ & ind & neut & $00 \mathrm{~m}$ & 000 & erg & neut & $0 \mathrm{~m} 0$ & 000 & $\begin{array}{l}\text { Haspelmath } \\
1993\end{array}$ \\
\hline Nivkh & Nivkh & neut & neut & 000 & 000 & neut & neut & 000 & 000 & Panfilov 1965 \\
\hline Turkish & Turkic (Altaic) & ind & neut & $\mathrm{mmm}$ & 000 & acc & acc & $00 \mathrm{~m}$ & $\mathrm{~mm} 0$ & Kornfilt 1997 \\
\hline Udmurt & Finnic (Uralic) & ind & neut & $\mathrm{mmm}$ & 000 & acc & acc & $00 \mathrm{~m}$ & $\mathrm{~mm} 0$ & $\begin{array}{l}\text { Perevoščikov } \\
1962\end{array}$ \\
\hline $\begin{array}{l}\text { Yukaghir } \\
\text { (Kolyma) }\end{array}$ & Yukaghir & ind & neut & $\mathrm{mmm}$ & 000 & acc & acc & $00 \mathrm{~m}$ & $\mathrm{~mm} 0$ & Maslova 2003 \\
\hline \multicolumn{11}{|l|}{$\begin{array}{l}\text { SEAsia \& } \\
\text { Oceania }\end{array}$} \\
\hline Cambodian I & \multirow{2}{*}{ Khmer (Mon-Khmer) } & ind & neut & $00 \mathrm{~m}$ & 000 & \multirow{2}{*}{ neut } & \multirow[t]{2}{*}{ neut } & \multirow[t]{2}{*}{000} & \multirow{2}{*}{000} & \multirow{2}{*}{ Jacob 1968} \\
\hline Cambodian II & & neut & neut & 000 & 000 & & & & & \\
\hline Cantonese & Chinese (Sino-Tibetan) & neut & neut & 000 & 000 & neut & neut & 000 & 000 & $\begin{array}{l}\text { Matthews \& } \\
\text { Yip } 1994\end{array}$ \\
\hline Dong I & \multirow[t]{2}{*}{ Kam-Tai } & neut & neut & 000 & 000 & \multirow[t]{2}{*}{ neut } & \multirow[t]{2}{*}{ neut } & \multirow[t]{2}{*}{000} & \multirow[t]{2}{*}{000} & \multirow{2}{*}{$\begin{array}{l}\text { Long \& Zheng } \\
1998\end{array}$} \\
\hline Dong II & & ind & neut & $00 \mathrm{~m}$ & 000 & & & & & \\
\hline $\begin{array}{l}\text { Dulong/Rawan } \\
\mathrm{g}\end{array}$ & Nungish (Tibeto-Burman) & ind & neut & $00 \mathrm{~m}$ & 000 & erg & neut & $0 \mathrm{~m} 0$ & 000 & LaPolla 2000 \\
\hline Garo & Baric (Tibeto-Burman) & ind & neut & $\mathrm{mmm}$ & 000 & $\mathrm{acc}$ & neut & $00 \mathrm{~m}$ & 000 & Burling 1961 \\
\hline Hyow & $\begin{array}{l}\text { Kuki-Chin-Naga (Tibeto- } \\
\text { Burman) }\end{array}$ & ind & sec & $00 \mathrm{~m}$ & $\mathrm{~m} 0 \mathrm{~m}$ & erg & acc & $0 \mathrm{~m} 0$ & $\mathrm{mmm}$ & Peterson 2003 \\
\hline $\begin{array}{l}\text { Kayah Li } \\
\text { (Eastern) }\end{array}$ & Karen (Tibeto-Burman) & neut & neut & 000 & 000 & neut & neut & 000 & 000 & Solnit 1997 \\
\hline Khmu & $\begin{array}{l}\text { Palaung-Khmuic (Mon- } \\
\text { Khmer) }\end{array}$ & ind & neut & $00 \mathrm{~m}$ & 000 & neut & neut & 000 & 000 & $\begin{array}{l}\text { Svantesson } \\
1983\end{array}$ \\
\hline Kiribatese & Oceanic (Austronesian) & neut & neut & 000 & 000 & neut & acc & 000 & $\mathrm{~mm} 0$ & $\begin{array}{l}\text { Groves et al. } \\
1985\end{array}$ \\
\hline Indonesian I & \multirow[t]{2}{*}{ Sundic (Austronesian) } & neut & neut & 000 & 000 & \multirow[t]{2}{*}{ neut } & \multirow[t]{2}{*}{ neut } & \multirow[t]{2}{*}{000} & \multirow[t]{2}{*}{000} & \multirow[t]{2}{*}{ Sneddon 1996} \\
\hline Indonesian II & & ind & neut & $00 \mathrm{~m}$ & 000 & & & & & \\
\hline Ladakhi & Tibetic (Tibeto-Burman) & ind & neut & $00 \mathrm{~m}$ & 000 & erg & neut & $0 \mathrm{~m} 0$ & 000 & Koshal 1979 \\
\hline Semelai & Aslian (Mon-Khmer) & ind & neut & $\mathrm{mmm}$ & 000 & trip & erg & $0 \mathrm{~mm}$ & $0 \mathrm{~m} 0$ & Kruspe 2004 \\
\hline Taba & $\begin{array}{l}\text { S Halmahera-NW N. G. } \\
\text { (Austronesian) }\end{array}$ & neut & neut & 000 & 000 & neut & erg & 000 & $\mathrm{~mm} 0$ & Bowden 2001 \\
\hline Tagalog I & \multirow[t]{2}{*}{ Philippine (Austronesian) } & ind & neut & $\mathrm{mmm}$ & 000 & \multirow[t]{2}{*}{ erg } & \multirow[t]{2}{*}{ neut } & $\mathrm{mmm}$ & 000 & Schachter \& \\
\hline Tagalog II & & $\mathrm{sec}$ & neut & $\mathrm{mmm}$ & 000 & & & & & Otanes 1972 \\
\hline Vietnamese & Viet-Muong (Mon-Khmer) & neut & neut & 000 & 000 & neut & neut & 000 & 000 & Nguyen 1997 \\
\hline $\begin{array}{l}\text { Australia \& } \\
\text { NG }\end{array}$ & & & & & & & & & & \\
\hline Imonda & Border & ind & trip & $\mathrm{mmm}$ & $\mathrm{mmm}$ & acc & acc & $00 \mathrm{~m}$ & $\mathrm{mmm}$ & Seiler 1985 \\
\hline Kobon & $\begin{array}{l}\text { East N G Highlands } \\
\text { (Trans-NG) }\end{array}$ & neut & neut & 000 & 000 & neut & acc & 000 & $\mathrm{~mm} 0$ & Davies 1981 \\
\hline Lavukaleve & $\begin{array}{l}\text { Solomons E. Papuan (East } \\
\text { Papuan) }\end{array}$ & ind & ind & $00 \mathrm{~m}$ & $\mathrm{~mm} 0$ & neut & acc & 000 & $\mathrm{mmm}$ & Terrill 2003 \\
\hline Mangarrayi & Mangarrayi & neut & $\mathrm{sec}$ & $\mathrm{mmm}$ & $\mathrm{m} 0 \mathrm{~m}$ & trip & acc & $0 \mathrm{~mm}$ & $\mathrm{mmm}$ & Merlan 1982 \\
\hline Maranungku & Daly & neut & $\mathrm{sec}$ & 000 & $\mathrm{~m} 0 \mathrm{~m}$ & neut & acc & 000 & $\mathrm{mmm}$ & Tryon 1970 \\
\hline Martuthunira & Pama-Nyungan & neut & neut & $\mathrm{mmm}$ & 000 & acc & neut & $00 \mathrm{~m}$ & 000 & Dench 1995 \\
\hline Motuna & $\begin{array}{l}\text { East Bougainville (East } \\
\text { Papuan) }\end{array}$ & neut & $\mathrm{sec}$ & 000 & $\mathrm{~m} 0 \mathrm{~m}$ & erg & trip & $0 \mathrm{~m} 0$ & $\mathrm{mmm}$ & Onishi 2000 \\
\hline Nabak & $\begin{array}{l}\text { Finisterre-Huon (Trans- } \\
\text { New Guinea) }\end{array}$ & neut & $\sec$ & 000 & $\mathrm{~m} 0 \mathrm{~m}$ & neut & acc & 000 & $\mathrm{mmm}$ & $\begin{array}{l}\text { Fabian et al. } \\
1998\end{array}$ \\
\hline Ndjébbana & Ndjébbana & neut & $\mathrm{sec}$ & 000 & $\mathrm{~m} 0 \mathrm{~m}$ & neut & trip & 000 & $\mathrm{mmm}$ & McKay 2000 \\
\hline Tauya & $\begin{array}{l}\text { Brahman (Trans-New } \\
\text { Guinea) }\end{array}$ & neut & $\mathrm{sec}$ & 000 & $\mathrm{~m} 0 \mathrm{~m}$ & erg & acc & $0 \mathrm{~m} 0$ & $\mathrm{mmm}$ & $\begin{array}{l}\text { MacDonald } \\
1990\end{array}$ \\
\hline Tidore I & Northern Halmahera (West & ind & neut & $00 \mathrm{~m}$ & 000 & neut & $\mathrm{acc}$ & 000 & $\mathrm{~mm} 0$ & van Staden \\
\hline Tidore II & Papuan) & neut & neut & 000 & 000 & & & & & 2000 \\
\hline Suena & $\begin{array}{l}\text { Binanderean (Trans-New } \\
\text { Guinea) }\end{array}$ & ind & neut & $00 \mathrm{~m}$ & 000 & neut & acc & 000 & $\mathrm{~mm} 0$ & Wilson 1974 \\
\hline Wambaya & West Barkly & neut & $\sec$ & 000 & $\mathrm{~m} 0 \mathrm{~m}$ & erg & trip & $0 \mathrm{~m} 0$ & $\mathrm{mmm}$ & $\begin{array}{l}\text { Nordlinger } \\
1998\end{array}$ \\
\hline Wardaman & Gunwinyguan & neut & sec & $\mathrm{mmm}$ & $\mathrm{m} 0 \mathrm{~m}$ & erg & trip & $\mathrm{mmm}$ & $\mathrm{mmm}$ & Merlan 1994 \\
\hline Yimas & Nor-Pondo (Sepik-Ramu) & neut & ind & 000 & $\mathrm{mmm}$ & neut & trip & 000 & $\mathrm{mmm}$ & Foley 1991 \\
\hline $\begin{array}{l}\text { North } \\
\text { America }\end{array}$ & & & & & & & & & & \\
\hline Bella Coola & Bella Coola (Salishan) & $\mathrm{sec}$ & $\mathrm{sec}$ & $0 \mathrm{~m} 0$ & $\mathrm{~m} 0 \mathrm{~m}$ & neut & trip & 000 & $\mathrm{mmm}$ & Davis \& \\
\hline
\end{tabular}




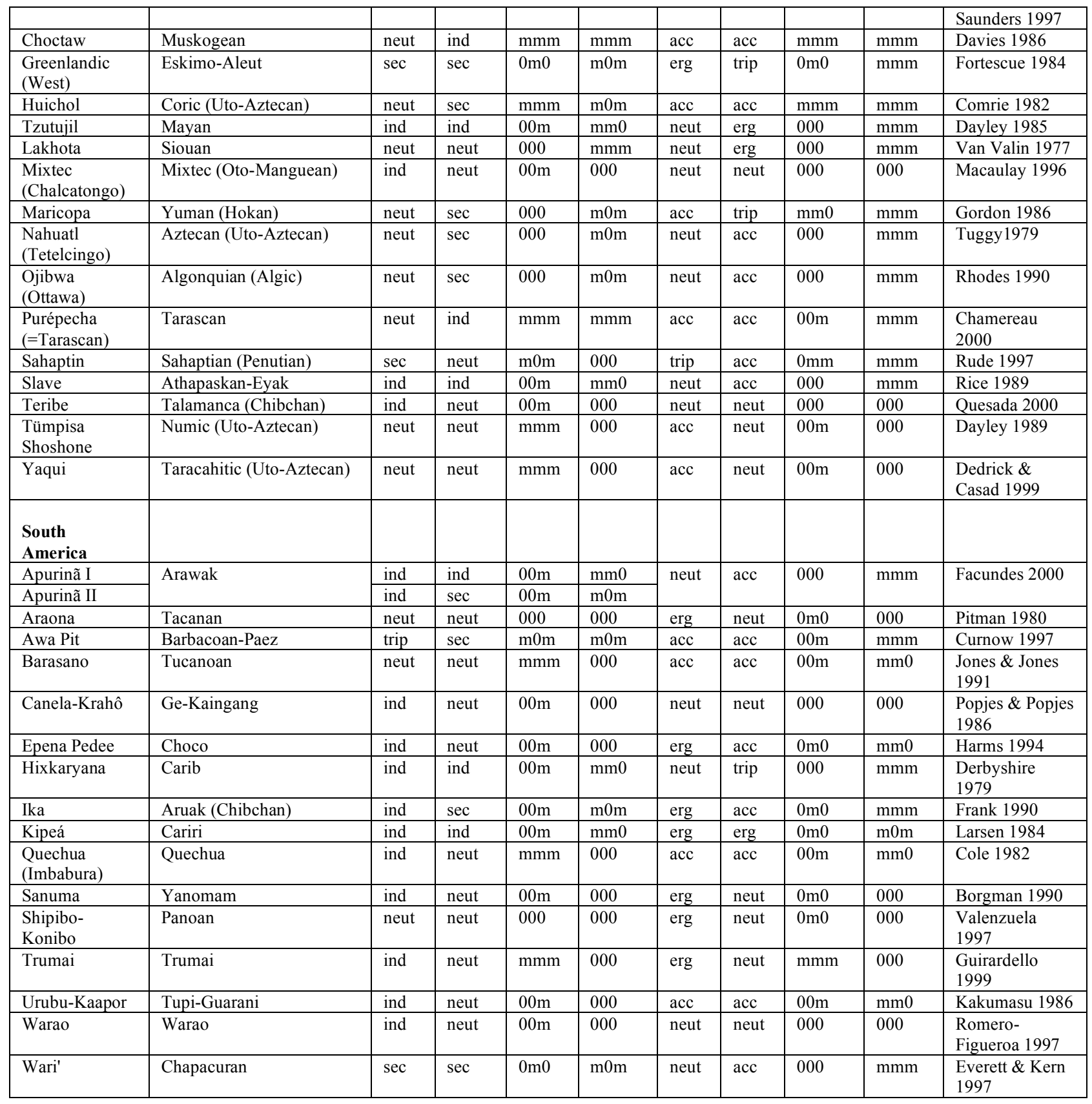

\section{References for the table}

Borgman, Donald M. 1990. Sanuma. Handbook of Amazonian languages 2, ed. Desmond C. Derbyshire and Geoffrey K. Pullum, 15-248. Berlin: Mouton de Gruyter.

Bowden, John. 2001. Taba: Description of a South Halmahera language. Pacific Linguistics, 521. Canberra: Australian National University.

Burling, Robbins. 1961. A Garo grammar. Deccan College Monograph Series 25. Pune: Deccan College Postgraduate and Research Institute.

Cain, Bruce D., and James W. Gair. 2000. Dhivehi (Maldivian). München: Lincom Europa.

Carlson, Robert. 1994. A grammar of Supyire. Mouton Grammar Library 14. Berlin: Mouton de Gruyter.

Chamereau, C. 2000. Grammaire du purépecha parlé sur des iles du lac de Patzcuaro. München: Lincom Europa.

Cole, Peter. 1982. Imbabura Quechua. Lingua Descriptive Studies 5. Amsterdam: North-Holland.

Comrie, Bernard. 1982. Grammatical relations in Huichol. Studies in transitivity, Syntax and Semantics 15, ed. by Paul J. Hopper and Sandra A. Thompson, 95-115. New York: Academic Press. 
Curnow, Timothy J. 1997. A Grammar of Awa Pit (Cuaiquer): An indigenous language of western Colombia. Australian National University Ph.D. Thesis.

Cyffer, Norbert. 1991. We learn Kanuri. Afrikawissenschaftliche Lehrbücher 2. Köln: Rüdiger Köppe.

Davies, H. John. 1981. Kobon. Lingua Descriptive Studies 3. Amsterdam: North-Holland.

Davies, William D. 1986. Choctaw verb agreement and universal grammar. Dordrecht: D. Reidel Pub. Co.

Davis, Philip W., and Saunders, Ross. 1997. A grammar of Bella Coola. Occasional Papers in Linguistics 13. Missoula, Montana: University of Montana.

Dayley, Jon P. 1985. Tzutujil grammar. University of California Publications in Linguistics 107. Berkeley: University of California Press.

-----. 1989. Tümpisa (Panamint) Shoshone grammar. University of California Publications in Linguistics 115. Berkeley: University of California Press.

Dedrick, John M., and Eugene H. Casad. 1999. Sonora Yaqui language structures. Tucson: University of Arizona Press.

Dench, Alan Charles. 1995. Martuthunira: A language of the Pilbara Region of Western Australia. Pacific Linguistics, Series C125. Canberra: Dept. of Linguistics, Research School of Pacific and Asian Studies, Australian National University.

Derbyshire, Desmond C. 1979. Hixkaryana. Lingua Descriptive Studies 1. Amsterdam: North-Holland.

Dunn, Michael John. 1999. A grammar of Chukchi. Australian National University Ph.D. Dissertation.

Ebert, Karen Heide. 1979. Sprache und Tradition der Kera (Tschad). Volume 3: Grammatik. Berlin: Reimer.

Everett, Daniel L., and Barbara Kern. 1997. Wari': the Pacaas Novos language of Western Brazil. Descriptive Grammar Series. London: Routledge.

Fabian, Grace, Edmund Fabian, and Bruce Waters. 1998. Morphology, syntax and cohesion in Nabak, Papua New Guinea. Pacific Linguistics, Series C-144. Canberra: ANU.

Facundes, Sidney da Silva. 2000. The language of the Apurinã people of Brazil (Maipure/Arawak). State University of New York, Buffalo Ph.D. Dissertation.

Fischer, Wolfdietrich. 1972. Grammatik des klassischen Arabisch. Wiesbaden: Harrassowitz.

Foley, William A. 1991. The Yimas language of New Guinea. Stanford: Stanford University Press.

Fortescue, Michael. 1984. West Greenlandic. Croom Helm Descriptive Grammars. London: Croom Helm.

Frank, Paul. 1990. Ika syntax. Studies in the Languages of Colombia 1. Arlington: Summer Institute of Linguistics and University of Texas at Arlington.

Gordon, Lynn. 1986. Maricopa morphology and syntax. University of California Publications in Linguistics 108. Berkeley: University of California Press.

Groves, Terab'ata R., Gordon W. Groves, and Roderick Jacobs. 1985. Kiribatese: An outline description. Pacific Linguistics, Series D-64. Canberra: ANU.

Guirardello, Raquel. 1999. A grammar of Trumai. Rice University, Houston, Texas, Ph.D. Dissertation.

Hagman, Roy Stephen. 1977. Nama Hottentot grammar. Research Center for Language and Semiotic Studies. Bloomington: Indiana University Press.

Harms, Philip Lee. 1994. Epena Pedee syntax. Studies in the Languages of Colombia 4. Arlington: Summer Institute of Linguistics and University of Texas, Arlington.

Harriehausen, Bettina. 1990. Hmong Njua: Syntaktische Analyse einer gesprochenen Sprache mithilfe datenverarbeitungstechnischer Mittel und sprachvergleichende Beschreibung des südostasiatischen Sprachraumes. Tübingen: Max Niemeyer Verlag.

Haspelmath, Martin. 1993. A grammar of Lezgian. Mouton Grammar Library 9. Berlin - New York: Mouton de Gruyter.

Heath, Jeffrey. 1999. A grammar of Koyraboro (Koroboro) Senni. The Songhay of Gao, Mali. Köln: Rüdiger Köppe Verlag.

Hewitt, B.George. 1979. Abkhaz. Lingua Descriptive Studies 2. Amsterdam: North Holland Publishing Company.

----. 1995. Georgian: A structural reference grammar. Amsterdam: John Benjamins.

Ikoro, Suanu. 1996. The Kana language. Leiden: Research School CNWS, Leiden University.

Jacob, Judith M. 1968. Introduction to Cambodian. London: Oxford University Press.

Jones, Wendell, and Paula Jones. 1991. Barasano syntax. Studies in the Languages of Colombia 2. Summer Institute of Linguistics and the University of Texas at Arlington Publications in Linguistics 101. Dallas: Summer Institute of Linguistics and the University of Texas at Arlington.

Kakumasu, James. 1986. Urubu-Kaapor. Handbook of Amazonian languages 1, ed. by Desmond C. Derbyshire and Geoffrey K. Pullum, 326-403. Berlin: Mouton de Gruyter.

Kenesei, István, Robert M. Vago, and Anna Fenyvesi. 1998. Hungarian. Descriptive Grammar Series. London: Routledge.

Kornfilt, Jaklin. 1997. Turkish. London: Routledge.

Koshal, Sanyukta. 1979. Ladakhi grammar. Edited by B.G. Misra. Delhi: Motilal Banarsidass.

Kruspe, Nicole. 2004. A grammar of Semelai. Cambridge: Cambridge University Press.

Lambdin, Thomas O. 1983. Introduction to Sahidic Coptic. Macon, Georgia: Mercer University Press.

LaPolla, Randy. 2000. Valency-changing derivations in Dulong/Rawang. Changing valency: case studies in transitivity, ed. by R.M.W. Dixon and Alexandra Y Aikhenvald, 282-311. Cambridge: Cambridge University Press.

Larsen, T.W. 1984. Case marking and subjecthood in Kipea Kiriri. Berkeley Linguistics Society 10: 189-205.

Long, Yaohong and Zheng Guoqiao. 1998. The Dong Language in Guizhou Province, China. Translated from Chinese by D. Norman Geary. Publications in Linguistics 126. Dallas: Summer Institute of Linguistics and the University of Texas at Arlington. 
Macaulay, Monica. 1996. A Grammar of Chalcatongo Mixtec. University of California Publications in Linguistics 127 . Berkeley: University of California Press.

MacDonald, Lorna. 1990. A grammar of Tauya. Mouton Grammar Library 6. Berlin: Mouton de Gruyter.

Maslova, Elena. 2003. A Grammar of Kolyma Yukaghir. Mouton Grammar Library, 27. Berlin, New York: Mouton de Gruyter.

Matthews, Stephen, and Virginia Yip. 1994. Cantonese: A Comprehensive Grammar. New York: Routledge.

McKay, Graham. 2000. Ndjébbana. Handbook of Australian languages 5, ed. by R.M.W. Dixon and Barry J. Blake, eds., 154354. Oxford: Oxford University Press.

Merlan, Francesca C. 1994. A grammar of Wardaman: A language of the Northern Territory of Australia. Mouton Grammar Library 11. Berlin: Mouton de Gruyter.

----. 1982. Mangarayi. Lingua Descriptive Studies 4. Amsterdam: North-Holland.

Minassian, Martiros. 1980. Grammaire d'arménien oriental. Delmar, N.Y.: Caravan Books.

Newman, Paul. 2000. The Hausa language: An encyclopedic reference grammar. New Haven, CN: Yale University Press.

Nguyen, Đinh-Hoa. 1997. Vietnamese. London Oriental and African Language Library 9. Amsterdam: John Benjamins.

Noonan, Michael. 1992. A grammar of Lango. Mouton Grammar Library 7. Berlin: Mouton de Gruyter.

Nordlinger, Rachel. 1998. A grammar of Wambaya, Northern Territory (Australia). Pacific Linguistics, Series C-140. Canberra: ANU.

Onishi, Masayuki. 2000. Transitivity and valency-changing derivations in Motuna. Changing valency, ed. by R.M.W. Dixon and Alexandra Y. Aikhenvald, eds., 115-44. Cambridge: Cambridge University Press.

Owens, Jonathan. 1985. A grammar of Harar Oromo (Northeastern Ethiopia). Hamburg: Buske.

Panfilov, V. Z. 1965. Grammatika Nivxskogo Jazyka. Moscow: Akademia Nauk SSSR.

Penchoen, Thomas G. 1973b. Tamazight of the Ayt Ndhir. Afroasiatic Dialects 1. Los Angeles: Undena Publications.

Perevoščikov, Petr N., ed. 1962. Grammatika sovremennogo udmurtskogo jazyka: fonetika i morfologija. Iževsk: Udmurtskoe knižnoe izdatel'stvo.

Peterson, David A. 2003. Agreement and grammatical relations in Hyow. Language variation: Papers on variation and change in the Sinosphere and in the Indosphere in honour of James A. Matisoff, ed. by David Bradley, Randy LaPolla, Boyd Michailovsky and Graham Thurgood, 173-83. Canberra: Australian National University, 173-83.

Pitman, Donald. 1980. Bosquejo de la gramática araona. Notas lingüísticas 9. Riberalta, Bolivia: Instituto lingüístico de verano.

Plungian, Vladimir. 1995. Dogon. Languages of the World/Materials 64. München: Lincom Europa.

Popjes, Jack, and Jo Popjes. 1986. Canela-Krahô. Handbook of Amazonian languages 1, ed. by Desmond C. Derbyshire and Geoffrey K. Pullum, 128-199. Berlin: Mouton de Gruyter.

Quesada, J. Diego. 2000. A grammar of Teribe. München: Lincom Europa.

Reh, Mechthild. 1985. Die Krongo-Sprache (Niinò Mó-Di). Berlin: Dietrich Reimer Verlag.

Rhodes, Richard. 1990. Ojibwa secondary objects. Grammatical relations: A cross theoretical perspective, ed. by Katarzyna Dziwirek, Patrick Farrell, and Errapel Mejías-Bikandi, 401-414. Stanford: CSLI.

Rice, Keren. 1989. A grammar of Slave. Mouton Grammar Library 5. Berlin: Mouton de Gruyter.

Romero-Figueroa, A. 1997. A reference grammar of Warao. Lincom Studies in Native American Linguistics 6. München: Lincom Europa.

Rowlands, Evan Colyn. 1969. Teach yourself Yoruba. London: English Universities Press.

Rude, Noel. 1997. Dative shifting and double objects in Sahaptin. Grammatical relations: a functionalist perspective, ed. by Talmy Givón, 323-349. Amsterdam: Benjamins.

Saltarelli, Mario, Miren Azkarate, David Farwell, Jon Ortiz de Urbina, and Lourdes Oñederra. 1988. Basque. Croom Helm Descriptive Grammars. London: Croom Helm.

Schachter, Paul, and Fé T. Otanes. 1972. Tagalog reference grammar. Berkeley: University of California Press. [reprinted in 1983]

Seiler, Walter. 1985. Imonda, a Papuan language. Pacific Linguistics, Series B-93. Canberra: The Australian National University.

Serzisko, Fritz. 1992. Sprechhandlungen und Pausen: Diskursorientierte Sprachbeschreibung am Beispiel des Ik. Tübingen: Niemeyer.

Shibatani, Masayoshi. 1990. The languages of Japan. Cambridge Language Surveys. Cambridge: Cambridge University Press.

Sneddon, James N. 1996a. Indonesian reference grammar. St. Leonards, Australia: Allen and Unwin.

Solnit, David B. 1997. Eastern Kayah Li: Grammar, texts, glossary. Honolulu: University of Hawaii Press.

Soukka, M. 2000. A descriptive grammar of Noon. Lincom Studies in African Linguistics 40. München: Lincom Europa.

Sridhar, S.N. 1989. Kannada: Descriptive grammar. Croom Helm Descriptive Grammars London: Routledge.

Stevenson, R.C. 1969. Bagirmi grammar. Linguistic Monograph Series 3. Khartoum: Sudan Research Unit, University of Khartoum.

Svantesson, Jan-Olof. 1983. Kammu phonology and morphology. Travaux de l'Institut de Linguistique de Lund 18. Malmö: CWK Gleerup.

Terrill, Angela. 2003. A grammar of Lavukaleve. Berlin: Mouton de Gruyter.

Tröbs, Holger. 1998. Funktionale Sprachbeschreibung des Jeli (West-Mande). Mande languages and linguistics 3. Köln: Rüdiger Köppe Verlag.

Tryon, Darrell T. 1970. An introduction to Maranungku. Pacific Linguistics, Series B-15. Canberra: The Australian National University.

Tuggy, David H. 1979. Tetelcingo Nahuatl. Studies in Uto-Aztecan grammar, volume 2: modern Aztec grammatical sketches, ed. 
by Ronald W. Langacker, 1-140. Dallas: Summer Institute of Linguistics, University of Texas, Arlington.

Valenzuela, Pilar. 1997. Basic verb types and argument structures in Shipibo-Conibo. University of Oregon M.A. Thesis.

van Staden, Miriam. 2000. Tidore: A linguistic description of a language of the North Moluccas. Leiden: University of Leiden Ph.D. Thesis.

Van Valin, Robert D. 1977. Aspects of Lakhota syntax. University of California at Berkeley Ph.D. Dissertation.

Wilson, Darryl. 1974. Suena grammar. Workpapers in Papua New Guinea Languages 8. Ukarumpa, Papua New Guinea: Summer Institute of Linguistics.

Ziervogel, Dirk, Jacobus A. Louw, and Petrus C. Taljaard. 1981. A Handbook of the Zulu Language. Pretoria: J. L. van Schaik.

\section{References}

Brown, Lea. 2005. Nias. The Austronesian languages of Asia and Madagascar, ed. by K. Alexander Adelaar and Nikolaus P. Himmelmann, 562-589. London: Routledge,.

Bybee, Joan L. 1988. The diachronic dimension in explanation. Explaining language universals, ed. by John A. Hawkins, 350-379. Oxford: Blackwell.

-----. 2003. Los mecanismos de cambio como universales lingüísticos. En Torno a Los Universales Lingüísticos, ed. by R. Mairal and J. Gil, 245-263. Cambridge: Cambridge University Press. 245-263. [English original version available from author's website]

Comrie, Bernard. 1978. Ergativity. Syntactic typology, ed. by Winfred P. Lehmann, 329-94. Austin: University of Texas Press,.

----- 1982. Grammatical relations in Huichol. Studies in transitivity, Syntax and Semantics 15, ed. by Paul J. Hopper and Sandra A. Thompson, 95-115. New York: Academic Press.

Croft, William. 1990. Typology and universals. Cambridge: Cambridge University Press.

Davies, William D. 1986. Choctaw verb agreement and universal grammar. Dordrecht: Kluwer.

Dayley, Jon P. 1985. Tzutujil grammar. University of California Publications in Linguistics 107.

Berkeley: University of California Press.

Dixon, R.M.W. 1994. Ergativity. Cambridge: Cambridge University Press.

Dryer, Matthew. 1986. Primary objects, secondary objects, and antidative. Language 62: 808-45.

----- 1989. Large linguistic areas and language sampling. Studies in Language 13:257-92.

-----. 2005. Genealogical language list. The world atlas of language structures, ed. by Martin Haspelmath, Matthew S. Dryer, David Gil and Bernard Comrie, 584-644. Oxford: Oxford University Press.

-----. To appear. Clause types. To appear Language typology and syntactic description, 2nd ed., ed. by Timothy Shopen. Cambridge: Cambridge University Press.

Givón, Talmy. 1976. Topic, pronoun and grammatical agreement. Subject and topic, ed. by Charles N. Li, 149-89. NewYork: Academic Press.

Greenberg, Joseph H. 1963. Some universals of grammar with particular reference to the order of meaningful elements. Universals of grammar, ed. by Joseph H. Greenberg, 73-113. Cambridge, Mass.: MIT Press.

Haspelmath, Martin. To appear. Creating economical morphosyntactic patterns in language change. Language universals and language change, ed. by Jeff Good. Oxford: Oxford University Press.

-----. 2005. Ditransitive constructions: The verb 'Give'. The world atlas of language structures, ed. by Martin Haspelmath, Matthew S. Dryer, David Gil and Bernard Comrie, 426-9. Oxford: Oxford University Press. 
Haspelmath, Martin \& Matthew S. Dryer \& David Gil \& Bernard Comrie (eds.) 2005. The world atlas of language structures. Oxford: Oxford University Press.

Lazard, Gilbert. 1994. L'actance. Paris: Presses Universitaires de France.

Lehmann, Christian. 1995. Thoughts on grammaticalization. Munich: Lincom Europa.

Moravcsik, Edith. 1974. Object-verb agreement. Working Papers in Language Universals 15: 25140.

Newman, John. 1996. Give: a cognitive linguistic study. (Cognitive Linguistics Research 7.) Berlin: Mouton de Gruyter.

Noonan, Michael. 1992. A grammar of Lango. (Mouton Grammar Library, 8.) Berlin: Mouton de Gruyter.

Parodi, Teresa. 1998. Aspects of clitic doubling and clitic clusters in Spanish. Models of inflection, ed. by Ray Fabri, Ray, Albert Ortmann and Teresa Parodi, 85-102. Tübingen: Niemeyer.

Peterson, David A. 2003. Agreement and grammatical relations in Hyow. Language variation: Papers on variation and change in the Sinosphere and in the Indosphere in honour of James A. Matisoff, ed. by David Bradley, Randy LaPolla, Boyd Michailovsky and Graham Thurgood, 173-83. Canberra: Australian National University, 173-83.

Plank, Frans (ed.) 1979. Ergativity: Towards a theory of grammatical relations. New York: Academic Press.

Rowlands, E.C. 1969. Yoruba. (Teach Yourself Books) Sevenoaks, Kent: Hodder \& Stoughton.

Rude, Noel. 1997. Dative shifting and double objects in Sahaptin. Grammatical relations: A functionalist perspective, ed. by Talmy Givón, 323-349. Amsterdam: Benjamins.

Siewierska, Anna. 1996. Word order type and alignment type. Sprachtypologie und Universalienforschung 49.2: 149-176.

-----. 2003. Person agreement and the determination of alignment." Transactions of the Philological Society 101.2: 339-370.

----. 2004. Person. Cambridge: Cambridge University Press.

WALS: see Haspelmath et al. 2005.

Wichmann, Søren. 2005. Tlapanec cases. Conference on Otomanguean and Oaxacan languages, March 19-21, 2004, University of California at Berkeley. (Report 13, Survey of Californian and Other Indian Languages), ed. by Rosemary Beam de Azcona and Mary Paster, 133-145. Berkeley: UC Berkeley.

Author's contact information:

Martin Haspelmath

Max Planck Institute for Evolutionary Anthropology

Deutscher Platz 6

D-04103 Leipzig, Germany

haspelmath@eva.mpg.de 